Article received on January $16^{\text {th }} 2017$

Revised version accepted on May $16^{\text {th }} 2018$

UDC: $784.4: 355.257 .7(=163.41)(439.5) " 1915 / 1918 "$

\author{
Nice Fracile* \\ University of Novi Sad \\ Academy of Arts \\ Department of Musicology and Ethnomusicology
}

\title{
THE PHONOGRAPHIC RECORDINGS OF TRADITIONAL MUSIC PERFORMED BY SERBIAN PRISONERS OF WAR (1915-1918) ${ }^{1}$
}

\begin{abstract}
This paper will focus on an examination of the phonographic recordings of traditional music, as performed by Serbian war prisoners during World War One (19151918) in the German camps of Königsbrück and Parchim. These recordings of traditional Serbian songs and instrumental tunes were made on the spot by the German researcher Georg Schünemann. This is a unique and outstandingly valuable source - in terms of quantity, quality and scientific approach - providing material about Serbian folklore from the early $20^{\text {th }}$ century. The author of this paper will examine the basic poetic/musical features of that material, the difficulties in deciphering the recordings and the identifica-

\footnotetext{
*Author contact information: nicefracile@gmail.com

1 This paper was presented at the 21st Symposium of the International Council for Traditional Music, Study Group on Historical Sources of Traditional Music, held in Paris, France, March 9-13 2016.
} 
tion of the informants, and also the continuity and changes in the style of performing those songs and instrumental tunes, which can still be heard sung and played in Serbia - in comparison to the musical folklore material from the early $20^{\text {th }}$ century. Moreover, the significance and current relevance of the material for Serbian ethnomusicology will be highlighted, considering the fact that it has not been accessible to the scholarly public so far.

Keywords: phonographic recordings, wax cylinders, Serbian prisoners, German camps, Königsbrück, Parchim, poetic/musical features, dactylic form, heterometric and heterorhythmic structure.

\section{Introductory notes}

As early as the beginning of the $20^{\text {th }}$ century, researchers in Serbia who studied traditional music pointed out the necessity of using a phonograph in their work in order to record musical folklore materials as precisely and truthfully as possible. Yet this device was not available to them before the 1930's. ${ }^{2}$ It was in this decade that Serbian researchers - ethnologist Borivoje Drobnjaković and composer Kosta Manojlović - made the first recordings of Serbian traditional songs. ${ }^{3}$

${ }^{2}$ The famous Serbian composer Mokranjac was aware of the difficulties in the efforts to record folkloric material which the lack of adequate devices posed for sound recording and reproduction; thus, he said once: "In order to make such recording more reliable, a phonograph should be provided into which the singers should sing, while the expert should truthfully put whatever is sung into notation thereafter" (Стеван Стојановић Мокрањац, Етномузиколошки записи, Драгослав Девић (прир.) Београд-Књажевац, Музичкоиздавачко предузеће "Нота“", Завод за уџбенике и наставна средства, 1996, XV). As his wish was never fulfilled, he continued to put down tunes 'by ear', that is, straight from the informants.

${ }^{3}$ The audio recordings of Serbian musical folklore material by foreign researchers, made for commercial purposes during the first decades of the 20th century, fall beyond the subject of this paper. The phonographic recordings of Serbian and Romanian traditional music made by Béla Bartók across Banat in 1912 were among the first to be made, using a scholarly approach. For more on that, see: Нице Фрациле, “Записи Беле Бартока са банатских простора”, Зборник Матице српске за сиенске уметности и музику, 16-17, 1995, 5376; Nice Fracile, "In the Wake of Bartók's Recordings. The Changes and Evolutionary Tendencies in the Serbian and Romanian Folklores in Vojvodina, Yugoslavia", in: East European Meetings in Ethnomusicology, 2nd volume, Marin Marian Bălaşa (ed.), Bucharest, Marin Marian Bălaşa, 1995, 15-23; Nice Fracile, "Bartók Béla: Szerb népzenei gyüjtése Fonogramok a Bánátból 1912. Szerb zenei hagyományok I" (Collection of Phonographic Recordings of Serbian Folk Music from Banat, 1912. Legacy of Serbian Folk Music I), Нови Звук, интернационални часопис за музику, 37/I, 2011, 107-109; Nice Fracile, “The Manners of 
Unfortunately, most of the wax cylinders from those times have been damaged, and there are few which can be deciphered and used for scholarly purposes. ${ }^{4}$ But there is one unique and outstandingly valuable source - in terms of quantity, quality and scientific approach - providing material about Serbian folklore from the early $20^{\text {th }}$ century: phonographic recordings of traditional music performed by Serbian prisoners of war during World War One (1915-1918) in the German camps of Königsbrück and Parchim. ${ }^{5}$ These recordings of traditional Serbian songs and instrumental tunes were made on the spot by the German musicologist Georg Schünemann.

This paper focuses on examining the basic poetic/musical features of that material, on the difficulties encountered in deciphering the recordings and the identification of the informants, and also on the continuity and changes in the style of performing those songs and instrumental tunes, which can still be heard sung and/or played in Serbia - in comparison to the musical folklore material from the early $20^{\text {th }}$ century. Attention is paid to the general morphological features, too. Moreover, the significance and current relevance of the material for Serbian ethnomusicology are highlighted, considering the fact that it has not been accessible to the scholarly public so far.

During World War One, some 220,000 soldiers of the Army of the Kingdom of Serbia found themselves in prison camps, sharing the destiny of about $8,000,000$ prisoners of war in the same period. ${ }^{6}$ The largest number of these Serbs, more than 154,000, were imprisoned in Austria-Hungary; some 40,000 in Bulgaria; according to German statistical sources, thought to be extremely pre-

Performance in Historical Recordings of the Serbian and Romanian Traditional Music", in: Proceedings of the Regional Conference Research, Preservation and Presentation of Banat Heritage: Current State and Long Term Strategy (Vršac, Serbia, 17-19 November 2011), Vršac: City Museum of Vršac, 2012, 157-164.

${ }^{4}$ For more about this research, see: Dragoslav Dević, Etnomuzikologija, I i II deo (skripta), Beograd, Fakultet muzičke umetnosti, 1981, XVII; Растко Јаковљевић (ур.), “Фоноархив Музиколошког института САНУ: историјски звучни записи у дигиталној ери”, Београд, Музиколошки институт САНУ, 2014, (CD-ROM), 20-24.

${ }^{5}$ I wish to express my gratitude to Professor Dr. Lars-Christian Koch, Director of the Ethnological Museum in Berlin, and Dr. Susanne Ziegler for having confidence in me and allowing me the privilege to study and evaluate the phonographic recordings of the Serbian traditional music performed by the prisoners of war from Serbia during World War One. My thanks are also due to my colleague Ms. Adelajda Merchán-Drazkowska whose generous help and kindness I enjoyed during my study visit to Berlin.

${ }^{6}$ Cf. Dalibor Denda, "Serbian POWs in the Great War", Collection of Works, vol. 30, Srdjan Rudić and Miljan Milkić (eds.), Beograd, Strategic Research Institute, Institute of History, 2015, 287. 
cise, and there were 28,746 prisoners from Serbia in Germany, and they made up 1.14 percent of the total number of prisoners of war in that country. ${ }^{7}$ Most of the captives were held in 47 prison camps on German territory. The camps included Königsbrück near Dresden, and Parchim near Hamburg. ${ }^{8}$ Among the prisoners in these camps, there were some from Serbia who sang and/or played traditional music from the folkloric heritage of the Kingdom of Serbia.

\section{An overview of the musical folklore material}

The musical folklore material collected by Georg Schünemann and deposited at the Ethnological Museum in Berlin was recorded on a phonograph on 63 wax cylinders. Altogether, there are 85 recorded items taken from 18 Serbian captives: 51 items fall within vocal or vocal-instrumental tradition, and 34 within instrumental tradition. Those are lyric, epic and old town songs, as well as patriotic and combat songs; also, there are two choral songs, two inspired by the life of seamen, one wedding song, one serenade, one satirical song and the national anthem entitled God of Justice (Bože pravde). The instrumental corpus predominantly contains the tunes of the traditional songs and dances of the Serbs; others include signal, pastoral, epic melodies and spontaneous improvisations played on the violin, frula, bagpipe and gusle.

Some difficulties occurred when I set about writing down the lyrics of some songs and/or identifying the informants. The difficulties were due either to damage on the recordings or to the rather bad diction of some singers, and sometimes to incompleteness of the accompanying documentation. What proved to be of the utmost help were the cards of the informants with an identical questionnaire and their answers to the questions asked (name and surname, date and place of birth, national/ethnic identity, etc.). Although I did not have the cards of all the informants at my disposal, I did manage - on the basis of the sound recordings and the existing accompanying documents - to identify the informants from each recording individually. ${ }^{9}$ One of the questions each informant

\footnotetext{
${ }^{7}$ Cf. Dalibor Denda, op. cit., 282 apud: Jochen Oltmer, Unentberliche Arbeitskräfte - Kriegsgefangene in Deutschland 1914-1918, Kriegsgefangene im Europa des Erstens Weltkriegs, Hgb. von Jochen Oltmer, Krieg in der Geschichte, Hgb. von Stieg Förster, Bernhard R. Kroner und Bernd Weger, Band 24, Ferdinand Schöningh, Paderborn, München, Wien, Zürich 2006, 69 .

${ }^{8}$ Most of these recordings were made in Königsbrück.

${ }^{9}$ Cards have not been found for five informants, so there are no information on them available. Of the 13 cards, eight contain complete answers (to all of the questions) by the respective eight respondents.
} 
Questionnaires of the Serbian, Romanian and Romany informants

\section{Sa的B}

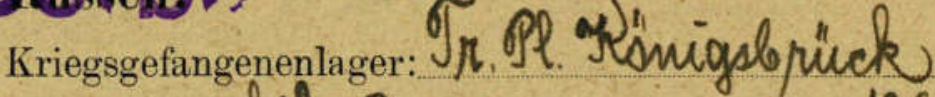

Baracke: Y.lag Stammrolle Nr.: 1365

Name (in der Muttersprache geschrieben):

Name (lateinisch geschrieben):

Vorname:

Wann geboren (Alter)? 5-I- 1879 ( 37 i a ahre)

Wo geboren (Heimat)? Treirikoswor

Welche gröBere Stadt liegt i.d. Nïhe des Geburtsortes?

Kreis (Ujezd):

Gouvernement (Gubernija): Zer: Posh arewar

Welchem Volksstamm angehörig? Yorb.

Welche Sprache als Muttersprache (Dialekt)? Yerbische

Welche Sprachen spricht er außerdem? heeine

Kann erlesen? nein WelcheSprachen? Reine

Kannerschreiben? nein Welche Sprachen? Kecine

Religion: Prth Beruf: Landmann

Spricht er deutlich und laut?

Kann er Gesänge seiner Heimat gut singen?

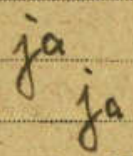

Spielt er ein im Lager vorhandenes Instrument aus seiner Heimat? ja

Singt oder spielt er moderneurropäische Musikweisen? Man

Ist anzunehmen, daß er gern in den Phonographen spreche oder singe? (Ja-Wahrscheinlich-UngewiB - Nein). Zutreffendes unterstreichen. 


\section{Serere}

Kriegsgefangenenlager: $\pi$. Pl ojumigsbruch

Baracke:

y Lag . Stammrolle Nr.: 2768

Name (in der Muttersprache geschrieben); Sagyadeuft

Name (lateinisch geschrieben):

Vorname:

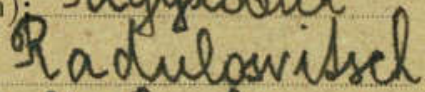

Wann geboren (Alter)? 20-I-1875 $4 i$ jahre)

Wo geboren (Heimat)?

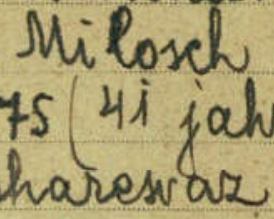

Welche gröBere Stadt liegt i.d. Nähe des Geburtsortes?

Kreis (Ujezd):

Tesharewar.

Gouvernement (Gubernija): Rez: Of osharesvas

Welchem Volksstamm angehörig?

Welche Sprache als Muttersprache (Dialekt)? Pumianisel

Welche Sprachen spricht er außerdem? Yerf. Rumanised

Kannerlesen? nein Welche Sprachen? leeine

Kann er schreiben? nein Welche Sprachen? lecine

Religion: Orth Beruf: Musileer

Spricht er deptlich und laut?

Kann er Gesänge seiner Heimat gut singen?

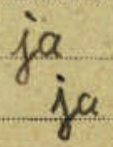

Spielt er ein im Lager vorhandenes Instrument aus seiner Heimat? Nein

Singt oder spielt er moderneuropäische Musikweisen?

Ist anzunehmen, daß er gern in den Phonographen spreche oder singe?

(Ja-Wahrscheinlich-Ungewiß-Nein). Zutreffendes unterstreichen. 


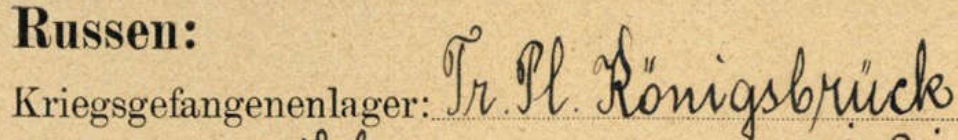
Baracke: Y.Lag Stammrolle Nr.: $108 i$ Name (in der Muttersprache geschrieben): Yolacuxoleut Name (lateinisch gesehrieben): Foswanowitsch

Vorname:

Wann geboren (Alter)? 13-i. 1892 ( 24

Wo geboren (Heimat)? Megaljixa

Welche größere Stadt liegti.d. Nähe des Geburtsortes?

Kreis (Ujezd):

Gouvernement (Gubernija): Grotschanski

Welchem Volksstamm angehörig? Yerb

Welche Sprache als Muttersprache (Dialekt)? Fiegajue

Welche Sprachen spricht er außerdem? ferb: Kiegajue Kann er lesen? Yerb. Welche Sprachen? Lerb Kann er schreiben? Yerb Welche Sprachen? Yerb. Religion: Orkh Beruf: Landmamn

Spricht er deutlich und laut?

Kann er Gesänge seiner Heimat gut singen?

Spielt er ein im Lager vorhandenes Instrument aus seiner Heimat?

Singt oder spielt er moderneuropäische Musikweisen?

Ist anzunehmen, daß er gern in den Phonographen spreche oder singe? (Ja-Wahrscheinlich-Ungewiß-Nein). Zutreffendes unterstreichen. 
was asked was whether he played an instrument available in the camp that came from his homeland. Three men gave affirmative answers: one played on a (borrowed) flute, and the other two played the bagpipe. ${ }^{10}$ The checkout of the cards showed that all of the respondents had Serbian citizenship, and that some of them were of non-Serb ethnic identity (three Romanians ${ }^{11}$ and one Romany ${ }^{12}$ ), which was partly reflected in their repertoire. However, this paper focuses on the presentation of Serbian traditional music. In terms of religion, all of the informants declared that they practised the Eastern Orthodox faith. ${ }^{13}$

In his search for additional information about those who managed to return to their families, the author of this paper tried to follow the lead provided by the Serbian prisoners/informants from whom the musical folkloric material was collected. One of the survivors was Voja Ivković of Veliko Gradište (1884-1946), who had sung two traditional songs: 'Kukuruzi već se beru' ('Corn Harvest Has Already Begun') and 'Mila moja Fata' ('My Darling Fata'; VII_W_0477_ Phon_Kom_453) and the national anthem of the Kingdom of Serbia 'God of Justice' ('Bože pravde'; VII_W_0478_Phon_Kom_454). On a photo from the camp, there is a written note: 'za uspomenu V. Ivk...kafedž' ('in remembrance, to V.Ivk...coff'), where the last and incomplete word could mean kafedžija, 'coffeehouse keeper'; yet on the reverse side of the picture one can read that he had for a while lived and been a bank clerk in Subotica. ${ }^{14}$

One of the most relevant and favourite ritual songs at Serbian wedding parties is entitled Odbi se biser grana od jorgovana (The Lilac Pearl-Twig Has

10 Jovan Aleksić, age 27 (date of birth not entered in the card), flute, Serb. Place of birth: illegible, region: Podrinje (Drina river valley); Marko Lazić, age 37, b. 05.01.1879, bagpipe, Serb. Place of birth: Čirikovac, region: Požarevac; Đorđe Aranđelović, age 29, b. 14.08.1887, bagpipe, Serb. Place of birth: Raunovo, region: Niš.

11 Jefta Marinković, age 27, b. 1.09.1889, violin, Romanian. Place of birth: Maove, region: Podrinje (Drina river valley); Mihajlo Kostić, age 22, b. 17.03.1894, violin, Romanian. Place of birth: Lipolist, region: Podrinje (Drina river valley); Miloš Radulović age 41, b. 20.01.1875, violin, Romanian. Place of birth: Požarevac, region: Požarevac. The abovesaid informants declared that their occupation was: "Müsiker" (i.e. musician).

${ }^{12}$ Radisav Jovanović, age 24, b. 13.01.1892, Romany. Place of birth: Begaljica, region: Belgrade.

${ }^{13}$ Four informants confirmed that they could neither read nor write in any language whatsoever: Marko Lazić, Đorđe Aranđelović (see footnote 10), Miloš Radulović and Mihajlo Kostić (see footnote 11).

${ }^{14}$ Voja Ivković was married to Savka, née Mišić, from Knjaževac. They had no offspring. Voja died at Veliko Gradište (1946). It is noteworthy that the famous Serbian violinist Vlastimir Pavlović Carevac was also imprisoned at that time as a member of a cadet unit. At this point and in this way, again, I wish to express my warm thanks to Mr. Žarko Živanović of Veliko Gradište for all the information and photos he made available to me. 


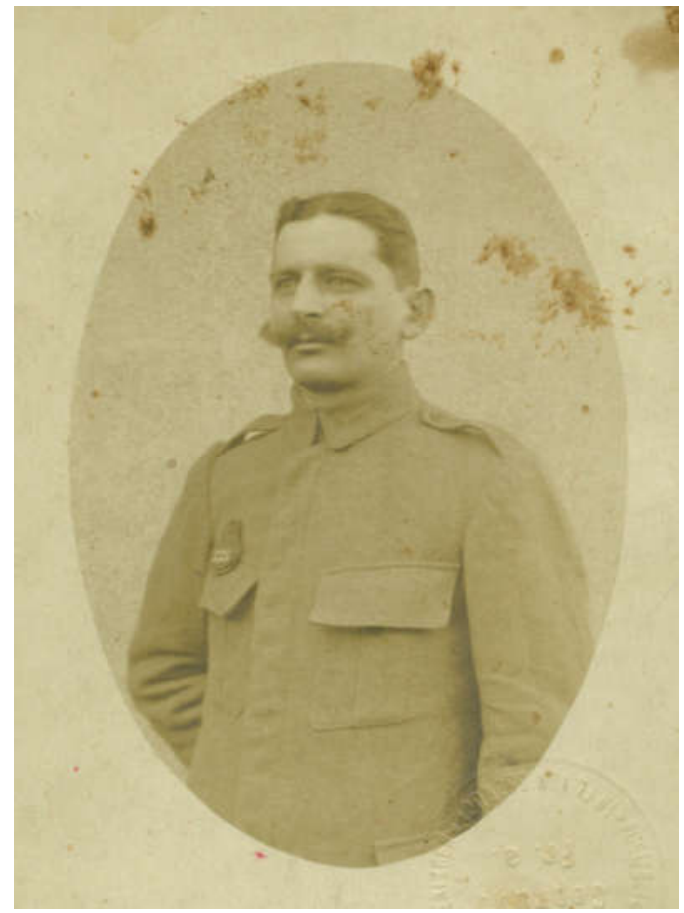

Portrait of Voja Ivković (1884-1946)

Come Off); ${ }^{15}$ it is quite typical of the Serbian folklore in Vojvodina. The musical notation of this and five other songs were published in Volume Two of Vuk Karadžić's Serbian Folk Songs (Srpske narodne pjesme), in 1815. ${ }^{16}$ In later periods, other melographers also published the lyrics and tunes of this wedding song; one of them was Béla Bartók, who recorded the song with his phonograph in Banat, in 1912. ${ }^{17}$ The same wedding song was sung by the Serbian prisoners of war Jefta Marinković and Mihajlo Kostić (VII_W_0442_Schuenemann_419):

${ }^{15}$ On the peculiarities of these strains and the melographers who have published them in various publications on the broad territory of the Danubian region see: Драгослав Девић, “Сватовска песма, Одби се грана од јоргована и особеност њеног напева", Зборник Матице српске за сиенске уметности и музику, 8-9, 1991, 125-131.

${ }^{16}$ Вук Стефановић Караџић, Народна србска пе̌снарица, частъ 2, Vienna, у Печатньи Іоанна Шнирера, 1815, 356-357.

17 For more on this, see: Нице Фрациле, “Записи Беле Бартока са банатских простора”, op. cit., 69; Nice Fracile, "In the Wake of Bartók’s Recordings. The Changes and Evolutionary Tendencies in the Serbian and Romanian Folklores in Vojvodina, Yugoslavia", op. cit., $15-23$. 


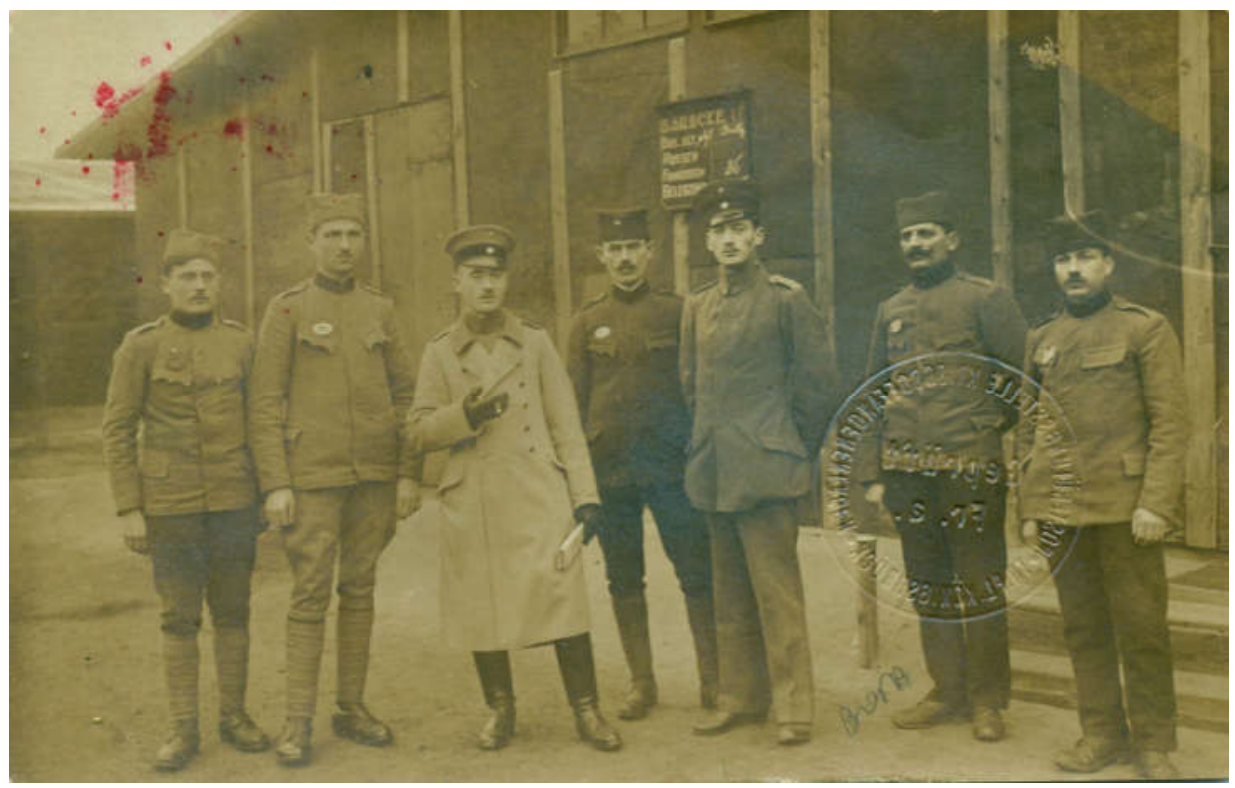

Voja Ivković with officers

\section{Text of the song}

\section{Odbi se biser grana od jorgovana}

Odbi se biser grana od jorgovana

I lepa, lepa Smilja, od tvoje majke.

Lepu Smilju odvedeše

Sa svircima ispratiše,

Svi je redom izljubiše,

Samo svircu ne dadoše.

Refren

/:Utvaraj, da, daj

Utvaraj, daj, daj.:/

\section{The Lilac Pearl-Twig Has Come Off}

The Lilac Pearl-Twig Has Come Off, And so has beautiful Smilja from her mother.

Beautiful Smilja was taken away,

With musicians playing at the farewell,

Everyone kissed her good-bye

But the player, forbidden to do the same.

Refrain

/:Just imagine, dah, dah, dye,

Just imagine, dah, dah, dye:/

The strains of this song can still be heard at Serbian wedding parties in Vojvodina, yet some lines in the lyrics have undergone a change, especially in the refrain, while the melodic type has remained almost the same. ${ }^{18}$

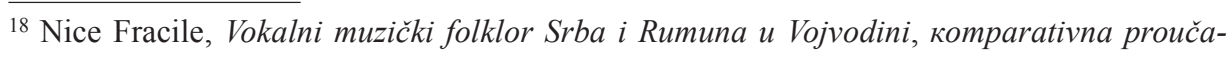
vanja, Novi Sad, Matica srpska, Udruženje folklorista Vojvodine, 1987, 183, 462-463. 
Although the available informants' cards reveal that they came from the Kingdom of Serbia, now mostly seen as Serbia Proper (Eastern, Central, Southeastern Serbia), their repertoire contained some songs from the folkloric heritage of Vojvodina. ${ }^{19}$ This refers to some lyrical songs, and this genre prevails in Georg Schünemann's collection of recordings. Among these, the song Širok Dunav, ravan Srem (Broad's the Danube, Srem's an Open Plain) stands out: it is performed by the singer and violinist Jefta Marinković, accompanied by the $\mathrm{Ka}$ pelle (VII_W_0449_NK_Phon_Kom_426). ${ }^{20}$ This lyrical song comes from the multinational (multicultural) Province of Vojvodina, the northern part of Serbia, and it is very popular even today. His performance is imbued with emotions, offering refined ornamentation and characteris ed by intrinsic musicalness. For easier understanding of the content of songs I tried to translate the verses from Serbian to English:

\section{Text of the song}

\section{Širok Dunav ravan Srem}

Širok Dunav ravan Srem hej, zbogom diko ja idem. Ne reći mi zbogom, zbogom, hej, već me vodi sa sobom.
'Broad's the Danube, Srem's an open plain, Broad's the Danube, Srem's an open plain, Don't say: So long, not so long, Hey, but do take me with you now'.

As one of the quite popular songs in Vojvodina, gladly and often sung to the present day, it is - both then and now - performed in the parlando rubato rhythmical system, whereby the lyrics and the melodic type remain almost the same or very similar. The song can be heard both in Vojvodina and in other folkloric regions of Serbia, as well as outside the country.

Considering the fact that the agelong tradition of singing epic poems to the accompaniment of the gusle across nearly all of the regions settled by the Serbs, such poems/songs are naturally part of the phonographic corpus recorded from the Serbian prisoners. Although the collectors and researchers of epic poetry have concluded that music is their significant coexistential prerequisite, it is as-

\footnotetext{
19 The region which was part of Austria-Hungary until the end of the Great War.

${ }^{20}$ Georg Schünemann used the term Kapelle (band, small orchestra) when referring to the joint performance of the four violinists (Jefta Marinković, Miloš Radulović, Mihajlo Kostić and Petar Jovanović), some of whom - according to need - play second violin ('contra'), or another section (a kind of counterpoint). Their performance reveals a higher level of art as compared to that by the flute or gusle players, which indicates the accuracy of the note in the informants' cards which specify their occupation as Musiker, i.e. 'musician'.
} 
sumed that research in the role of music found with the epic genre has been marginalis ed as compared with studies in the lyrics. ${ }^{21}$ Transcription work and the study of the messages and poetic/musical component in epic poems, especially of their melodic/rhythmic structure and performing style, in the a cappella interpretation by the Serbian prisoners of war $^{22}$, as well as the engrossing character of the lyrics (about Prince Marko, or the bravery and sufferings of the Serbian soldiers, or the assassination of King Aleksandar, etc.) pose a great challenge to researchers.

All of the recorded epic poems, including the one about the assassination of King Aleksandar Obrenović, are performed in decasyllabic lines, with coupled rhymes and asymmetric structure (4+6), within a few melodic types of syllabic or a moderately melismatic style of performance. To make up for the missing instrumental accompaniment which is, traditionally, the gusle, the informants resorted to imitation of the instrument by chanting out the vowel sounds ' $a$ ' or ' $\mathrm{O}$ '. This can be heard in the next illustration, the epic song about the assassination of King Aleksandar Obrenović (VII_W_0434_Phon_Kom_411). ${ }^{23}$ Following some consultations with fellow musicologists in Serbia and checks in the available ethnomusicological publications/writings, it can be assumed that, in all probability, the score/notation of this song has not been published in Serbia so far. ${ }^{24}$ As can be seen from the attached notation, the informant Radisav Jova-

${ }^{21} \mathrm{Cf}$. Данка Лајић Михајловић, Српско традиционално певање уз гусле: гусларска пракса као комуникациони процес, Београд, Музиколошки институт САНУ, 2014, 15-16. ${ }^{22}$ All of the recorded epic poems/songs are performed a cappella. There is only one specimen of a recorded epic poem/song that was performed to the accompaniment of the gusle; however, due to the poor diction of the singer, the lyrics are almost impossible to hear distinctly (and write down).

${ }^{23}$ The event, known as the 'May Overthrow' took place on May 29 ${ }^{\text {th }}, 1903$ : a group of army officers, led by Dragutin Dimitrijević Apis, killed the royal couple, which marked the end of the Obrenović dynasty.

${ }^{24}$ Cf. Миодраг А. Васиљевић, Народне мелодије лесковачког краја, Београд, Српска академија наука, Музиколошки институт,1960; Миодраг А. Васиљевић, Народне песме из Војводине, проф. др Драгослав Девић (прир.), Нови Сад, Матица српска, Завод за културу Војводине, 2009; Драгослав Девић, Народна музика Драгачева, Облици u развој, Београд, Факултет музичке уметности, 1986; Драгослав Девић, Народна музика Црноречја у светлости етногенетских процеса, Београд, Факултет музичке уметности, 1990; Драгослав Девић, Антологија српских и ирногорских народних песама с мелодијама, Београд, Карић Фондација, 2001; Dimitrije O. Golemović, Narodna muzika Podrinja (narodna muzička i igračka tradicija Podrinja), Sarajevo, Književna zadruga "Drugari”, 1988; Димитрије О. Големовић, Народна музика ужичког краја, Београд, Српска академија наука и уметности, Етнографски институт,1990; Димитрије О. Големовић, Пјевање уз гусле, Београд, Српски генеалошки центар, 2008; Данка Лајић Михајловић, 
nović pronounces the normally non-existent consonant ' $\mathrm{j}$ ' before the vowels ' $\mathrm{u}$ ' and ' $\mathrm{o}$ ' at the opening of some melostichs. ${ }^{25}$

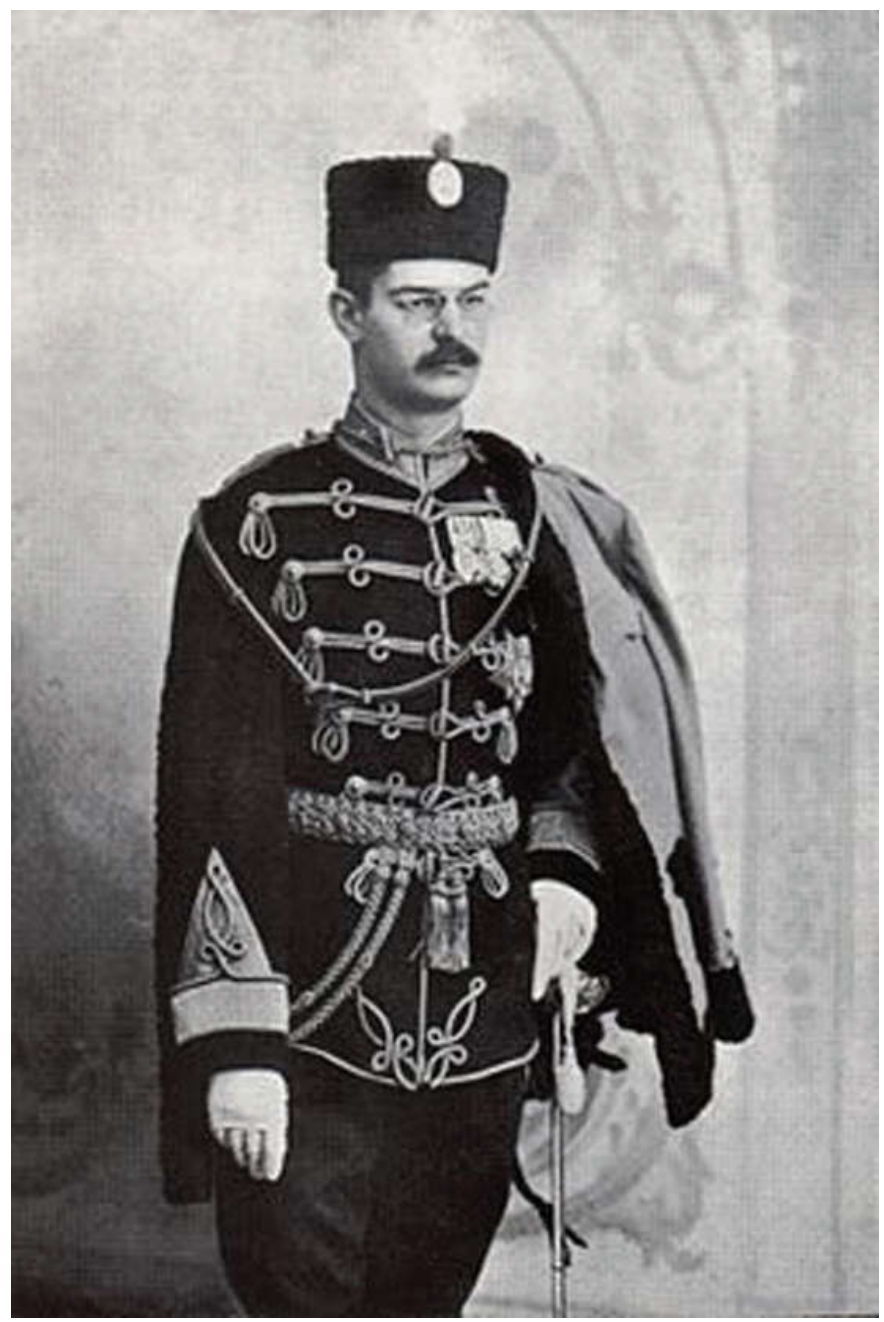

Portrait of Aleksandar Obrenović (1876-1903)

op. cit., 2014; Селена Ракочевић, Вокална традиција Срба у Доњем Банату, Београд, Завод за уџбенике и наставна средства, Скупштина општине Панчево, 2002; Nice Fracile, Vokalni muzički folklor Srba..., op. cit.

${ }^{25}$ Such pronunciation did not occur in the songs performed by the other informants. 


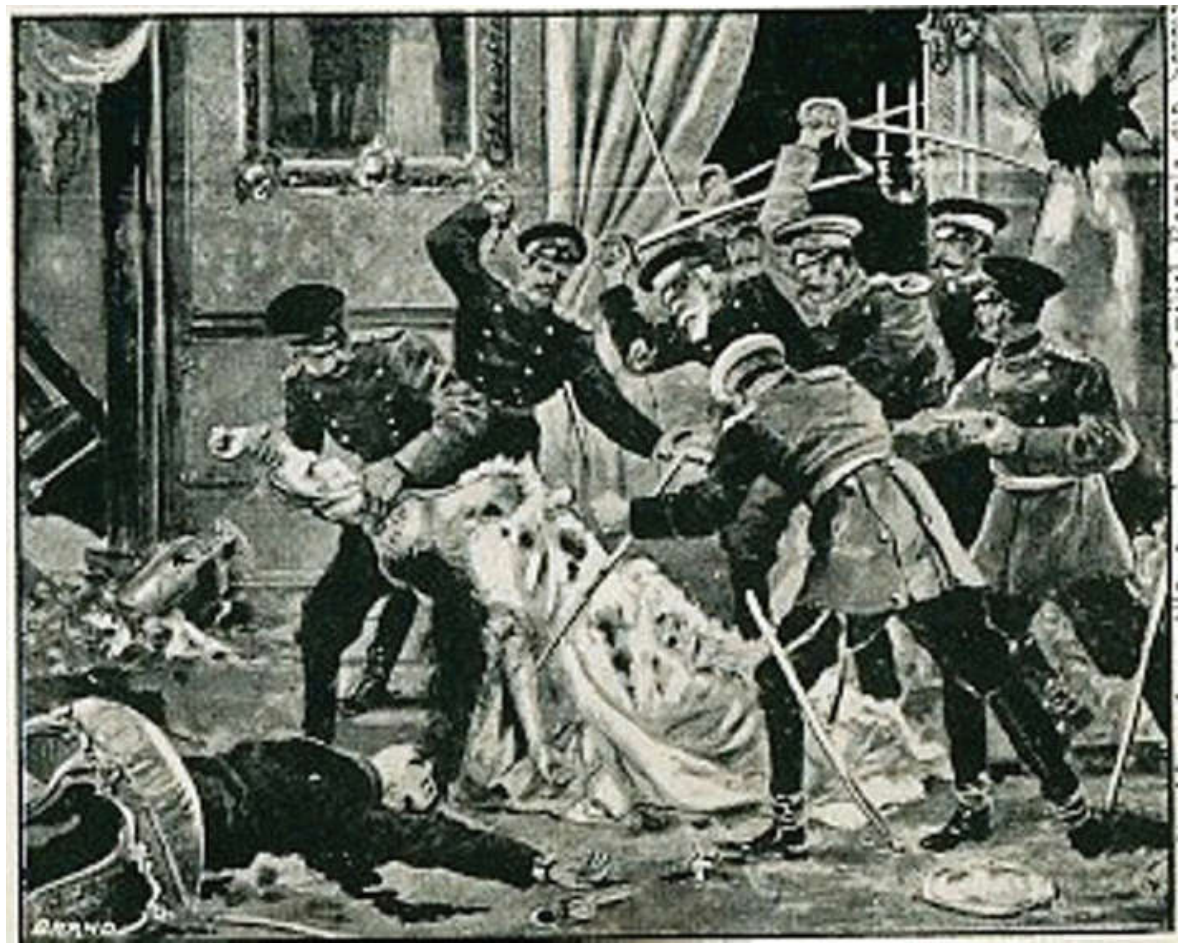

Scene of the massacre of King Aleksandar and his wife Draga

\section{Text of the song}

\section{(fragment)}

\section{Pesma o ubistvu}

\section{kralja Aleksandra Obrenovića}

a Bože mili, a Bože jedini,

Leti soko pa čudo kaziva,

Čujte, braćo, iz srpskog ${ }^{26}$ zemalja

jUbili su jAleksandra, kralja,

Pa kaži nam ti, sokole sivi,

Ko ga ubi, i što tako skrivi, jUbila ga protivnička ruka jOficiri od šestoga puk'.

\section{Song on the assassination} of King Aleksandar Obrenović oh, Our Lord, Our only God, Here flies a falcon telling something strange: Hear, O brothers, news from Serbian lands, Aleksandar, our King, has been slain.

Now, you will tell us, O you falcon grey, Who has slain him, what has his guilt been? He was slain by a rival hand, The officers of the Sixth Regiment.

${ }^{26}$ The correct form should read 'srpskih'. 


\section{SONG OF MURDER OF KING ALEKSANDAR}

VII_W_0434_Phon_Kom_411

Radisav Jovanović

Trans. Nice Fracile

21 November 1916

22 December 2016

Orig. Königsbrück

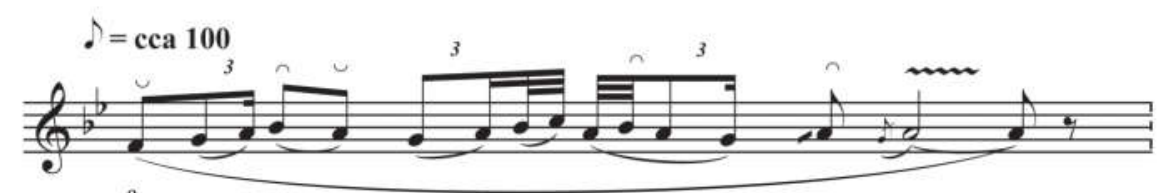

a,
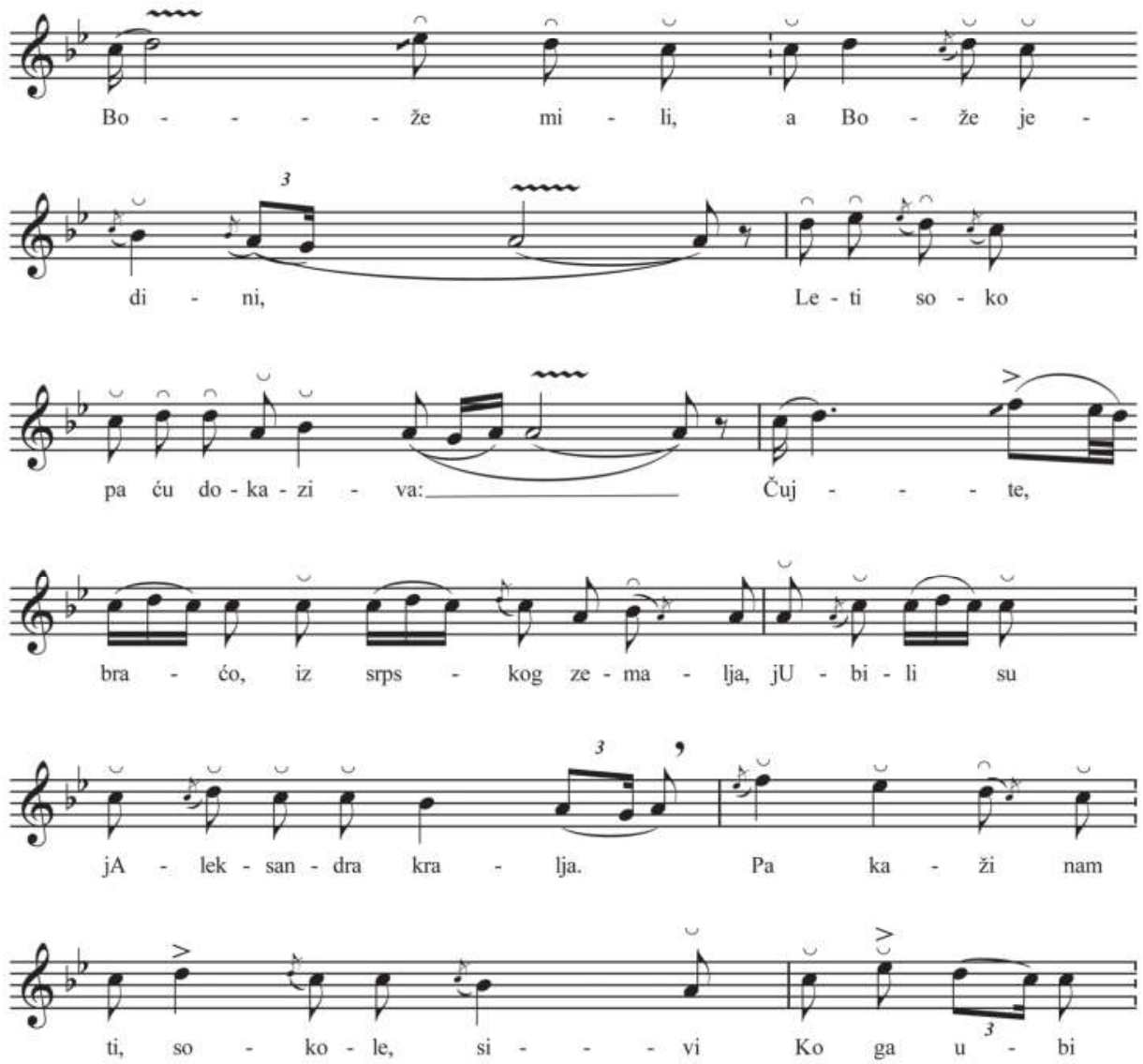
This historic body of phonographic recordings contains a number of songs that used to be sung by the Serbian prisoners at various fronts in the war. They describe the sufferings, the pain and sorrow, battle scenes and horrors; the soldiers of Serbia and Bosnia are encouraged to show their heroic virtue and bravery in the fight against the enemy, and eagerness to defend King Petar and liberate their country. The lyrics of the songs vary in terms of type (hexameter, heptameter, octosyllabic verse) and metric structure; each text corresponds to a particular melodic type. Most of the songs possess a solemn tone, and the melodic line is performed in a syllabic style and the distributive rhythmic system of two-part metrical division. Such is the following example, the song Serb and Bosnian Men (VII_W_0853_Phon_Kom_817):

\section{SERBS AND BOSNIANS}

VII_W_0853_Phon_Kom_817

Tran. N. Fracile

22 December 2016
Singer: Cvetko Josić, born ?

Orig. Parchim, 16 January 1918
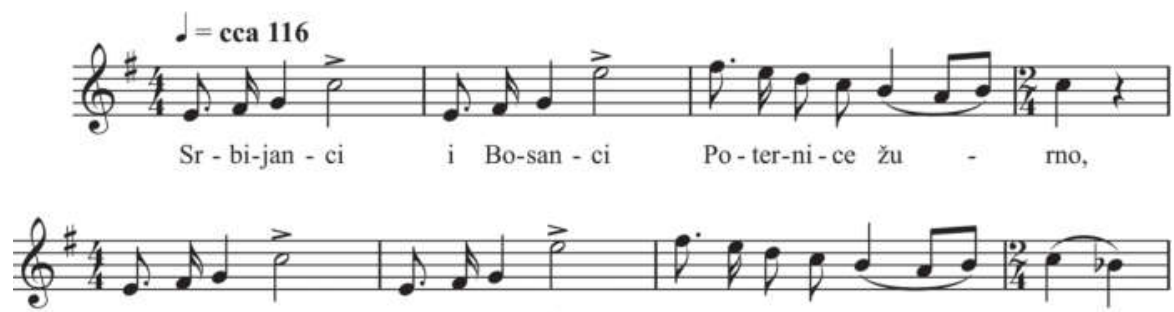

$E$ - vo te - pa sla - va če - ka

$\mathrm{U}$ to vre-me bur

no.

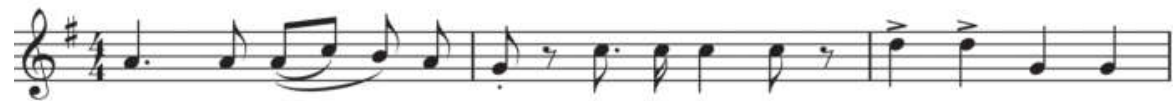

Raz - vi te_ se ču - (uj) mo kra - lja Kra - lja Pe - tra

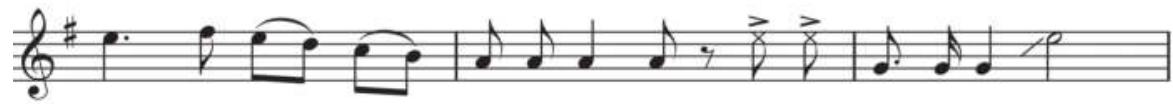

od meg-da - na Na-pred stu - paj, u - ra Ma - ši ru - kom,

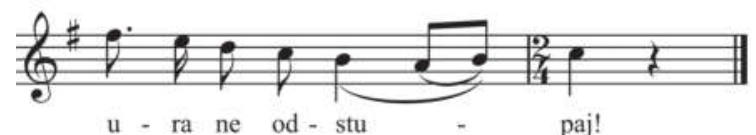

u - ra ne od - stu _ paj! 


\section{Text of the song}

\section{Srbijanci i Bosanci}

Srbijanci i Bosanci

Poternice, žurno,

Evo te pa slava čeka

U to vreme burno.

Razvi’te se, čujmo Kralja,

Kralja Petra od megdana.

Refren

Napred stupaj, ura!

Maši rukom, ura ne odstupaj!

\section{Serb and Bosnian Men}

Serb and Bosnian men,

Fast you carry out the chase,

And glory shall await you

In this time of storm.

Spread your lines and hear the King, King Petar of the battlefield.

Refrain

Forward you move, hurray!

Wield, hurray, do not retreat!

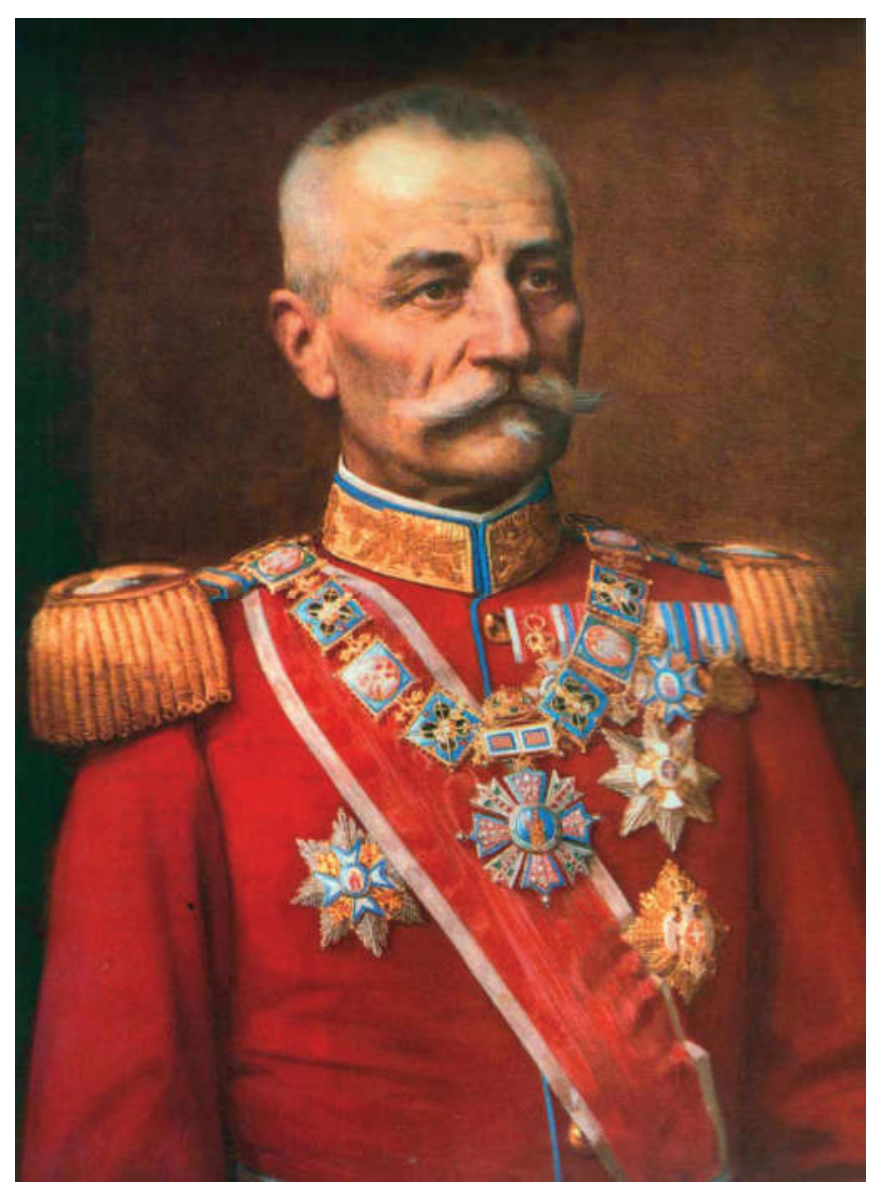

Portrait of King Petar Karađorđević (1844-1921) 
Instrumental music makes up a little more than one third of Schünemann's phonographic corpus. Among these recordings, most are done with violin players, and these mucisians proved to be very talented instrumentalists. They played solo, or as violin duos and quartets; within the Kapelle, each instrumentalist had a particular role. ${ }^{27}$ Their repertoire included a broad range of instrumental tunes of traditional, old-town and, partly, art music.

Although the epic verse is usually sung to the accompaniment of the $g u$ sle, the violinist Miloš Radulović proved, in an impressive and extremely subtle way, that narrative tunes (which are true gems regardless of the absence of vocalists) can be performed on his instrument. He did the same while performing a pastoral melody, as well as in a brilliant improvisation he called 'Nightingale' where he actually imitated the melodious sound of the lark. ${ }^{28}$ (VII_W_0443_ Phon_Kom_420).

Their interesting interpretations of the traditional Serbian dances - koloes (circle dances) - are particularly impressive. Bearing in mind the different ethnic backgrounds of these musicians, a search for these instrumental tunes in musical publications, sound archives and through field work could cast light on many issues that concern not only the origin of the melodies, but also their status in cross-influences between folkloric heritages of different cultures. Although the aksak rhythm is not characteristic of Serbian musical folklore, especially not of the folklore of Central Serbia, the wartime phonographic corpus contains some tunes which reflect the inter-penetration of metrorhythmic structure between the Serbian and another neighbouring nation. Biserka Kolo, ${ }^{29}$ in the dactylic form 7/16 (3+2+2) is such an example (VII_W_0461_Phon_Kom_438):

\section{General morphological features ${ }^{30}$}

Considering the period of a century since the musical folklore material of the Serbian prisoners was recorded, one can say that this body reveals some morphological features shared with the Serbian traditional music of the latter half of the $20^{\text {th }}$ century, and, to a lesser extent, the music of today. One of the funda-

\footnotetext{
${ }^{27}$ See footnote 20 .

${ }^{28}$ A similar phenomenon in Serbian folklore has been pointed out by Dimitrije Golemović (Dimitrije O. Golemović, "Kad instrument progovori”, Etnomuzikološki ogledi, Beograd, Biblioteka XX vek, 1997, 232).

29 The documentation provided fails to cite the title.

${ }^{30}$ The analysis of the morphological features of this musical folklore corpus is hampered due to the fact that many examples were recorded fragmentarily, for one wax cylinder could only record about two minutes of a text/music.
} 
Fracile, N.: The Phonographic Recordings of Traditional Music Performed...

\section{BISERKA KOLO}

VII_W_0461_Phon_Kom_438

Miloš Radulović, violin, born 1875

Tran. N. Fracile

Orig. Königsbrück, 1918

22 December 2016
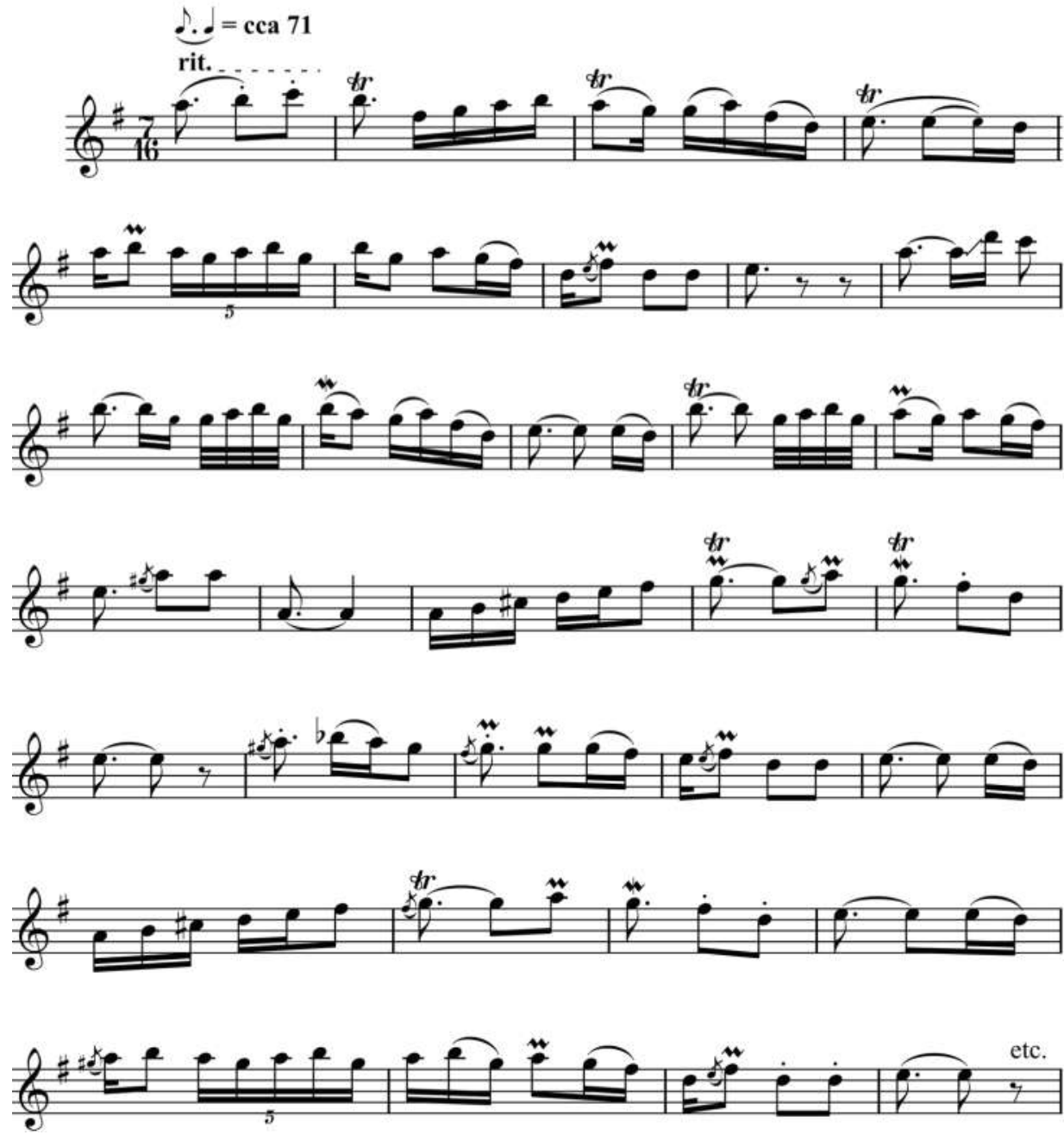
mental common elements is the poetic basis on which the lines of the recorded songs have been shaped. ${ }^{31}$ This is to say that the tunes of all the recorded epic songs follow the pattern of an asymmetrical decasyllable (4+6), and so do some of the lyrical and satirical songs (VII_W0434_Phon_Kom_411; VII_W0432_ Phon_Kom_409;). A number of songs, mostly old town songs (varoške pesme), alternately use two types of versification, e.g. the symmetrical octosyllable $(4+4)$ and the heptametre (4+3) (VII_W_0458_Phon_Kom_435); however, more than two types can also be found within one and the same song, e.g. nine metrical feet $(5+4)$, hexametre $(3+3)$, octosyllable $(5+3)$ and heptametre $(3+4)$ (VII_W_0439_Phon_Kom_416). Hence the prevalence of the heterometric and heterorhythmic structure in the examples of the vocal/vocal-instrumental tradition, regardless of the genre the songs fall within. Of the rhyiming schemes, the couplet (aabbcc) occurs most frequently, but the alternating scheme (abab) is found in some old town songs due to the influence of art poetry. In the analysed songs, refrains at the end of lines and mid-verse ones are found, but not as a frequent occurrence (VII_W_0841_Phon_Kom_805; VII_W_0440_Phon_Kom 417). The line-ending refrain prevails as an inseparable part of the melopoetic whole and is therefore considered to be 'dependent'. ${ }^{32}$ It is usually formed so as to follow one or two melostichs within a melopoetic whole.

The poetic texts of the epic songs are performed usually in the routine and easily identifiable voice of the Serbian gusle players (guslars), i.e. as a musical model which can even today be identified in the Serbian musical folklore treasury. The performing style varies, however, and is in correlation with the rhythmical systems. Thus, a melismatic or mildly melismatic performing style characteris es the epic songs that fall within the parlando rubato rhytmical system, while a syllabic style of performance is typical for those in the giusto syllabic rhythmical style. ${ }^{33}$ As for other folklore genres, such as lyrical, satirical, patriotic, combat songs or old town songs, their characteristics imply that each poetic text (lyirics) has a tune of its own. Hence the diversity of tone rows, ranging from the archaic ones such as pentachordia and hexachordia - via the Mixolydian, Aeolian or Dorian modes (with a fluctuation or alternation of some degrees and, not rarely, with an augmented second as an Oriental coloration) -

\footnotetext{
${ }^{31}$ In the opinion of some scholars, the lines in the Serbian songs were shaped within the syllabic-tonal versification system (Сања Радиновић, Морфологија српских народних песама 1, Beograd, Hema Kheya Neye, 2017, 8).

32 Cf. Димитрије О. Големовић, Рефрен у народном певању (од обреда до забаве), Београд, Реноме - Бјелина, Бања Лука, Академија уметности, 2000, 35.

${ }^{33}$ Cf. Nice Fracile, "The Manners of Performance in Historical Recordings of Serbian and Romanian Traditional Music", op. cit., 157-160.
} 
to the tonal structures which tend towards the major or minor mode (Examples $1,2)$. In the instrumental music, tone rows are conditioned by the constructional/technical potential of particular instruments - frula, bagpipe, dvojnci, violin (Example 3). Some tones in the tone rows here function as ornaments and include appoggiatura, less often Nachschlag, single or double pralltrillers, mordents, trillers, Gypsy trillers (refers to violinists) and gruppetto. In addition to the said embellishments, the means of expression used in the performances by the three excellent violinists mentioned above (Jefta Marinković, Mihajlo Kostić and Miloš Radulović) are manifest in the performing/interpretative manner of the professional 'pub-musicians' who show superb playing technique, inspired and spontaneous improvisation, the lively practice of nuances and rich articulation: portato, staccato, pizzicato, flageolet tones etc.

In his early $20^{\text {th }}$ century study "Cigani u Srbiji" ("The Gypsies in Serbia"), Vladimir Đorđević wrote: "Although the Gypsies have not been the sole "carriers' of Romanian music in Serbia, for it also arrived here with the Romanian people themselves, they doubtlessly deserve the greatest credit for that, as its best interpreters and as accomplished musicians. Coming to Serbia, they fostered Romanian music here, especially in Eastern Serbia where Romanians live en masse". ${ }^{34}$ Bearing in mind that Romanies often declared their nationality as one of the other peoples, the question arises of whether the three above-mentioned violinists were Romanians or Romanies.

The formal shaping of the examples of vocal and vocal-instrumental tradition shows extreme diversity, ranging from those based on the varied repetition of one melodic-rhythmical motif or one content in terms of the subject, to two, three or even four mutually different melodic sections/contrasting parts (VII_W_0496_Phon_Kom_472; VII_W_0437_Phon_Kom_414). The form of the instrumental tunes is in correlation with the types of the musical instruments and also with the adroitness and skill of the players themselves. Thus, the tunes performed on the frula or the bagpipes are predominantly shaped on the varied repetition of a single thematic content (VII_W_0456_Phon_Kom_433), while those played on the violin by 'professional' instrumentalists are built upon two, three or - at times - more contrasting sections (Example 3).

The rhythm in the analysed examples is based on the following rhythmic systems: parlando rubato, distributive, giusto syllabic, and aksak. The largest number of the examples of both vocal and vocal-instrumental tradition fall within the parlando rubato rhythmic system: it can be identified in the lyrical songs, old town songs, choral and some epic songs, the (recorded) wedding song, as

34 Тихомир Р. Ђорђевић, “Цигани и музика у Србији”, Босанска вила, бр. 3-6, Београд, $1910,77-78$. 
well as in the instrumental performances of signal, pastoral, epic melodies and improvisations on the violin, frula, bagpipe and gusle. The distributive rhythmic system, mostly of two-part metric structure, is also quite frequent in the lyrical, satirical, patriotic and combat songs, and the tunes for traditional dances, e.g. the kolos 'Srbijanka', 'Kukunjica', or 'Sitnica' - on different musical instruments. In a small number of examples one can hear giusto syllabic, basically in some epic songs of an earlier music layer, or the aksak rhythm in dance tunes.

It has to be said that during the first decades of the $20^{\text {th }}$ century, and - to some extent - later than that, in many transcriptions of traditional music by several European composers one could not (despite expectation) detect the existence of the asymmetrical aksak rhythm; this is due to inadequate notational transcription. Some phonographic recordings of the Serbian prioners of war make the most truthful and probably the earliest evidence that the violinists from/in Serbia had the tunes on their repertoire which fell within that rhythmic system, which was at that time still unknown to the European scholarly public. In the analysed examples, two forms of the aksak rhythm have been identified: dactyloid 7/16 $(3+2+2)$ and anapestoid $7 / 16(2+2+3)$ ones; the latter arrived through the influence of Bulgarian music on Serbian folklore (Example 3, VII_W_0461_Phon Kom_438; VII_W_0441_Phon_Kom_418). ${ }^{35}$

The metro-rhythmic pulsation of the recorded tunes is another mutually kindred or common element that can be recognised in present-day Serbian folklore. It reveals the vitality and continuity, yet also some changes in Serbian traditional music, as well as cross-penetrations of Serbian and other folklores in Southeastern Europe.

\section{Conclusion}

Based on my insight into the available phonographic recordings of some Serbian folk music from the second decade of the $20^{\text {th }}$ century, I find the musical folklore material provided by Georg Schünemann - first deposited and later digitalised at the Ethnological Museum in Berlin - to be of outstanding importance both to scholars and to performers or devotees of Serbian folklore. In all likelihood, this is the largest collection of non-commercial recordings of traditional Serbian music from the early $20^{\text {th }}$ century, established for scholarly purposes and unique for the fact that the recordings were made in a prison camp, during World War One, and not in times/conditions of peace. Its peculiarity also arises from the fact that

\footnotetext{
${ }^{35}$ For more about this cf. Nice Fracile, "Metroritmički obrasci aksak ritma u multikulturnoj Srbiji kao zajednička nit s folklorom susednih naroda", Зборник у част Марији Клеут, Нови Сад, Филолошки факултет, 2013, 194-199.
} 
some of the Serbian prisoners did not perform on their own instruments but on those which were available in the camp and had been brought from Serbia.

An additional issue may be raised: Under what conditions did the informants sing or play, considering the hatred spread through pre-war and wartime propaganda, especially so at the very beginning of the armed conflicts? Fuel (for heating) and food supplies were scarce even for the local citizens, let alone the captives. Scholarly works dealing with prisoners in the Great War inform about the better treatment of Serbian prisoners in Germany than in Bulgaria or Austria-Hungary. ${ }^{36}$ Yet most of the Serbian informants answered affirmatively to the question of whether they 'sang or spoke into the phonograph with pleasure'.

This material which has so far escaped the eye of the public will certainly prove beneficial not only to ethnomusicologists and ethnochoreologists, to folklorists and historians, but also to whoever wishes to learn more about the oral musical heritage and cultural values of the Serbian people. The corpus in question is an invaluable historical document, testifying to the national and cultural identity of the Serbs. In order to round off the picture of the traditional music of the Serbs in early $20^{\text {th }}$ history as a bridge between past and present, it would be recommendable to study and compare the phonographic recordings made by Béla Bartók in 1912 and the above-presented material obtained from the Serbian prisoners of war. Their publication would open the way to multifaceted research and possibly some fresh conclusions, which would - as said by Susanne Ziegler - provoke further research. ${ }^{37}$

\section{Works cited}

Denda, Dalibor: "Serbian POWs in the Great War". In: Collection of Works, vol. 30. Eds.: Srdjan Rudić and Miljan Milkić. Belgrade: Strategic Research Institute, Institute of History, 2015, 269-289.

Dević, Dragoslav: Etnomuzikologija, I i II deo (skripta). Beograd: Fakultet muzičke umetnosti, 1981.

Девић, Драгослав: Народна музика Драгачева. Облици и развој. Београд: Факултет музичке уметности, 1986.

Девић, Драгослав: Народна музика Црноречја у светлости етногенетских проиеса. Београд: Факултет музичке уметности, 1990.

${ }^{36}$ Dalibor Denda, op. cit., 287-288.

${ }^{37}$ Susanne Ziegler, "Historijski snimci bosanske muzike u Njemačkim arhivima", Sedmi međunarodni simpozij Muzika u društvu, Zbornik radova, Sarajevo, Muzikološko društvo FBiH, Muzička akademija u Sarajevu, 2010, 135. 
Девић, Драгослав: “Сватовска песма, Одби се грана од јоргована и особеност њеног напева". Зборник Матице српске за сиенске уметности и музику, 8-9, 1991, $125-131$.

Девић, Драгослав: Антологија српских и ирногорских народних песама с мелодијама. Београд: Карић Фондација, 2001.

Ђорђевић, Тихомир Р.: “Цигани и музика у Србији”. Босанска вила, бр. 3-6, Београд, 1910, 75-81.

Fracile, Nice: Vokalni muzički folklor Srba i Rumuna u Vojvodini, кomparativna proučavanja. Novi Sad: Matica srpska, Udruženje folklorista Vojvodine, 1987.

Фрациле, Нице: “Записи Беле Бартока са банатских простора”. Зборник Матице српске за сиенске уметности и музику, 16-17, 1995, 53-76.

Fracile, Nice: "In the Wake of Bartók's Recordings. The Changes and Evolutionary Tendencies in the Serbian and Romanian Folklores in Vojvodina, Yugoslavia”. In: East European Meetings in Ethnomusicology, 2nd volume. Ed.: Marin Marian Bălaşa. Bucharest: Marin Marian Bălaşa, 1995, 15-23.

Fracile, Nice: "Bartók Béla: Szerb népzenei gyüjtése Fonogramok a Bánátból 1912. Szerb zenei hagyományok I" (Collection of Phonographic Recordings of Serbian Folk Music from Banat, 1912. Legacy of Serbian Folk Music I). Нови Звук, интернационални часопис за музику, 37/I, 2011, 107-109.

Fracile, Nice: "The Manners of Performance in Historical Recordings of the Serbian and Romanian Traditional Music". In: Proceedings of the Regional Conference Research, Preservation and Presentation of Banat Heritage: Current State and Long Term Strategy. Vršac, Serbia 17-19 November 2011. Vršac: City Museum of Vršac, 2012, 157-164.

Fracile, Nice: "Metroritmički obrasci aksak ritma u multikulturnoj Srbiji kao zajednička nit s folklorom susednih naroda”. У: Зборник у част Марији Клеут. Нови Сад, Филолошки факултет, 2013, 191-216.

Golemović, Dimitrije O.: Narodna muzika Podrinja (narodna muzička i igračka tradicija Podrinja). Sarajevo: Književna zadruga "Drugari”, 1988.

Големовић, Димитрије О.: Народна музика ужичког краја. Београд: Српска академија наука и уметности, Етнографски институт, 1990.

Golemović, Dimitrije O.: “Kad instrument progovori”, U: Etnomuzikološki ogledi, Beograd: Biblioteka XX vek, 1997, 227-258.

Големовић, Димитрије О.: Рефрен у народном певању (од обреда до забаве). БеоградБања Лука: Реноме - Бјелина, Академија уметности, 2000.

Големовић, Димитрије О.: Пјевање уз гусле. Београд: Српски генеалошки центар, 2008.

Јаковљевић, Растко (ур.): “Фоноархив Музиколошког института САНУ: историјски звучни записи у дигиталној ери”. Београд: Музиколошки институт САНУ, 2014, (CD-ROM).

Караџић, Вук Стефановић: Народна србска пе̌снарица. Частъ 2. Vienna: У Печатньи Іоанна Шнирера, 1815.

Лајић Михајловић, Данка: Српско традиционално певање уз гусле: гусларска пракса као комуникащиони процес. Београд: Музиколошки институт САНУ, 2014. 
Мокрањац, Стеван Стојановић: Етномузиколошки записи. Прир.: Драгослав Девић (прир.). Београд - Књажевац: Музичко-издавачко предузеће "Нота", Завод за уџбенике и наставна средства, 1996.

Радиновић, Сања: Морфологија српских народних песама 1. Београд: Нета Кhеуа Neye, 2017.

Ракочевић, Селена: Вокална традищија Срба у Доњем Банату. Београд: Завод за уџбенике и наставна средства, Скупштина општине Панчево, 2002.

Васиљевић, Миодраг А.: Народне мелодије лесковачког краја. Београд: Српска академија наука, Музиколошки институт,1960.

Васиљевић, Миодраг А.: Народне песме из Војводине. Прир.: проф. др Драгослав Девић. Нови Сад: Матица српска, Завод за културу Војводине, 2009.

Ziegler, Susanne: "Historijski snimci bosanske muzike u Njemačkim arhivima". У: Zbornik radova. Sedmi međunarodni simpozij Muzika u društvu. Sarajevo: Muzikološko društvo FBiH, Muzička akademija u Sarajevu, 2010, 142-152.

\section{Summary}

The phonographic recordings of traditional music performed by Serbian prisoners of war represent a unique and outstandingly valuable source - in terms of quantity, quality and scientific approach - providing material about Serbian folklore from the early $20^{\text {th }}$ century. These recordings of traditional Serbian songs and instrumental tunes were made by the German researcher Georg Schünemann on the spot in the German camps of Königsbrück and Parchim during World War One (1915-1918). This paper focuses on the examination of the basic poetic/musical features of that material, on the difficulties in deciphering the recordings and identification of the informants, and also on the continuity and changes in the style of performing those songs and instrumental tunes which can still be heard sung and/or played in Serbia - in comparison to the musical folklore material from the early $20^{\text {th }}$ century.

The musical folklore material collected by musicologist Georg Schünemann and deposited at the Ethnological Museum in Berlin was recorded by phonograph on 63 wax cylinders. Altogether, there are 85 recorded items taken from 18 Serbian captives: 51 items fall within the vocal or vocal-instrumental tradition, and 34 within the instrumental tradition. They are lyrical, epic and old town songs, as well as patriotic and combat songs; also, there are two choral songs, two inspired by the life of seamen, one wedding song, one serenade, one satirical song and the national anthem entitled God of Justice (Bože pravde). The instrumental corpus predominantly contains the tunes of the traditional songs and dances of the Serbs; others include signal, pastoral, epic melodies and spontaneous improvisations played on the violin, frula, bagpipe, dvojnci and gusle.

Based on my insight into the available phonographic recordings of some Serbian folk music from the second decade of the $20^{\text {th }}$ century, I find the musical folklore material provided by Georg Schünemann to be of outstanding importance both to scholars and to 
performers or devotees of Serbian folklore. In all likelihood, this is the largest collection of non-commercial recordings of traditional Serbian music from the early $20^{\text {th }}$ century, established for scholarly purposes and unique for the fact that the recordings were made in a prison camp, during World War One, and not in times/conditions of peace. Its peculiarity also comes from the fact that some of the Serbian prisoners did not perform on their own instruments but on those which were available in the camp and had been brought from Serbia.

This material which has so far escaped the eye of the public will certainly prove beneficial not only to ethnomusicologists and ethnochoreologists, to folklorists and historians, but also to whoever wishes to learn more on the oral musical heritage and cultural values of the Serbian people. The corpus in question is an invaluable historical document, testifying to the national and cultural identity of the Serbs. In order to round off the picture of the traditional music of the Serbs in early $20^{\text {th }}$ century history as a bridge between past and present, it would be recommendable to study and compare the phonographic recordings made by Béla Bartók in 1912 and the above-presented material obtained from the Serbian prisoners of war. Their publication would open the way to multi-faceted research and possibly some fresh conclusions, which would - as Susanne Ziegler said - provoke further research. 